\title{
Investigating Students' Eyesights in the Utilization of Platforms in Learning ESP During the Covid-19 Pandemic
}

\author{
Multazam Abubakar ${ }^{1}$, Annisa Shofa Tsuraya ${ }^{2}$ \\ 1) 2) Universitas Islam Negeri Alauddin Makassar \\ 1) multazam.abubakar@uin-alauddin.ac.id \\ 2) annisa.tsuraya@uin-alauddin.ac.id
}

\begin{abstract}
The Covid-19 pandemic suddenly attacked the world and led every sector of life affected, including the education process, which is forced to shift into online mode. All educators are forced to adapt and find a learning platform to utilize in this emergency remote learning. This research uncovers the students' preference of digital platforms in learning ESP during the Covid-19 pandemic, the factors accepting their preference, and their perception of those learning platforms. The design of this study is qualitative. The participants of this study were 112 freshmen of a state university in Makassar who learn English for Specific Purposes (ESP), comprising 95 females and 17 males. The participants were consisted of 3 majors and involved in remote learning for one semester (16 meetings) through WhatsApp, Google Classroom, University LMS, YouTube, and Video Conference (Zoom and Google Meet). In order to collect the data, a questionnaire that consists of close-ended and open-ended questions was distributed to the participants. It is found that the students' preference of digital platform in learning ESP during the Covid-19 pandemic is WhatsApp. The factors affecting students' preference of the platform are demographic and economic constraints. The criteria of the application that is highly preferred by the students were the one which does not drain the internet quota, can still work correctly in which the internet connection is not strong, and can facilitate the interaction between lecturers and students. Finally, this study suggests that no one perfect digital platform can replace face-to-face learning since many things are missing during this online learning. So, to keep it running effectively, the combination of several platforms is required to be utilized.
\end{abstract}

Keywords: Students' preferences, learning platforms, remote learning, the Covid-19 pandemic.

\section{INTRODUCTION}

The Covid-19 pandemic brings the world to the most stressful condition. Various sectors get impacts of its outbreak. Economically, many people lost their jobs. The International Labor Organization (ILO) confirmed that in 2020 there were around 114 million people globally became unemployed due to the outbreak of coronaviruses (ILO, 2021); educationally, all educational institutions, starting from the kinder garden until university, are closed in order to avoid people of the Covid-19 exposure. As 
quoted from the official website of The United Nations Educational, Scientific and Cultural Organization (UNESCO), that until February 19, 2021 , there are more than 1,5 billion students and youth across the world have been affected by the closure of schools and universities due to the Covid-19 pandemic (UNESCO, 2021). To keep the academic activities going on, the government worldwide issue the policy to shift face-to-face learning into an online mode (Abidah et al., 2020; Rasmitadila et al., 2020).

The educators are forced to utilize technology to help them teach the students in remote learning. They have to adapt immediately to the condition and search for a suitable platform to facilitate them to teach in online mode (Zaharah et al., 2020). It then becomes the problem when they face the reality that not all students can access the technology. Some of the students who previously stayed in the city nearby their institution go back to their hometown. Whereas most of their hometown is located in remote areas in which the internet connection is unstable. This condition makes the learning process becomes ineffective (Febrianto et al., 2020).

Furthermore, inadequate facilities also limit the students to do perform maximally in online learning (Mulyadi, 2018; M. K. P. Rahayu, 2019). At the same time, teachers also feel that implementing online learning is not easy, and they face many difficulties in implementing online learning. Windiarti et al. ( 2019) find some obstacles to e-learning; they are devices for e- learning, teachers' knowledge, time management, and student motivation.

There are many varieties of platforms that are used to facilitate online learning, such as WhatsApp, Google Classroom, Video Conference (Zoom and Google Meet), YouTube, university LMS, etc. From the teachers' point of view, the appropriate platform can help them make the learning process effective. Using a video conference platform, for instance, the teacher can share their idea freely, and the quality of knowledge imparted is almost similar to teaching face-to-face. The teacher can talk a lot and share the materials directly, so the study atmosphere is very exquisite (Amoah \& Naah, 2020; Putra, 2020). Furthermore, to keep the students motivated in learning, the teachers must have an emotional attachment with students, vice versa (Kulal \& Nayak, 2020). However, from the students' point of view, using this kind of platform brings them many problems. They feel that it costs them money to buy more internet vouchers than other platforms. Besides, it also forces them to find a suitable place where the signal for internet connection runs well. Consequently, the students who reside in remote areas where the internet connection is terrible sometimes cannot attend the meeting, and finally, they are considered absent (Kheryadi, 2018; Mannong, 2020; Rahman, 2020). This condition leads many students to be stressed and does not enjoy the learning process. 
Students as the center of the learning process play an essential role in making it effective. Astri (2018) stated that students have dissimilar levels of motivation, different attitudes about teaching and learning, and diverse responses to specific classroom environment and instructional practices. Students' perception is vital since perception is closely related to students' motivation and performance. When the students perceive that online learning is beneficial for them, they will be more motivated and perform better in that course (L. Smart \& J. Cappel, 2006). Students' positive perceptions of the learning process positively impact their performance; on the other hand, the negative performance of students is affected by their negative perceptions (Ferreira \& Santoso, 2008).

Several studies have been published exploring students' perceptions of a digital platform to facilitate online learning during this pandemic period. A study by Amin \& Sundari (2020), conducted in Jakarta, Indonesia, and Aceh, uncovered that the students prefer digital platforms on the survey, Cisco WebEx Meeting video conferencing, Google Classroom learning management system, etc. WhatsApp mobile messenger application. Similarly, Rahman (2020) explored the students' perception of online learning and found that the students perceived online learning as helpful during the pandemic. However, they also thought that online learning was ineffective. He also investigated that the students prefer to learn using Learning
Management System (e.g., Google Classroom) and Social Media (e.g., WhatsApp, Telegram, and Facebook) instead of video conferencing (e.g., Zoom and Skype).

Furthermore, Mannong (2020) found that online learning improves students' digital literacy and some barriers to implementing online learning. Her study uncovers that the students perceived positive with the use of WhatsApp in learning English. Recently, Mulyani et al. (2021) also explored the e-learning implementation and found that WhatsApp is the most popular platform among the others; yet, this study does not investigate each platform's students' perception.

Despite the growing number of studies that have explored students' perception of digital learning platforms during the Covid-19 pandemic, most of the studies focus upon general teaching. Nevertheless, there have not been many published studies on the teaching of English for Specific Purposes (ESP) as there are many differences between the teaching of general English in EFL context and the teaching of ESP for pre-experience learners at the university level, such as in ESP the materials taught are not solely specific skills but integrate all aspects of language, including emphasizing reading and vocabularies of a particular field of study (Garrote, 2015). With this regard, this study attempts to investigate the students' preferences in the utilization of suitable platform that can be easily accessed by the students to make them enjoy the learning 
process in online mode, to reveal the factors that affect the students' preferences and to identify the reasons why the students prefer those learning platforms.

\section{LITERATURE REVIEW}

\section{Online learning}

The advancement of technology which has developed for decades also affects the education system all around the world. The influence of technology in the education system can be found in a learning mode that does not merely face-to-face in the classroom but can be done outside the class, that is, online learning. Online learning emphasizes internet-based courses (Rasmitadila et al., 2020). Meanwhile, Kulal \& Nayak (2020) define online learning as the use of technology and network communication for teaching and learning to learn subjects, discuss issues with fellow students, clarify doubts with an instructor, share material, and check academic progress help from internet-oriented technologies. However, during this pandemic, online learning is an obligation not only from the government but also from whom to minimize the effect of the Covid-19 on the students in all levels of education. Both teachers and students do not go to school and university but stay at home and take part in the virtual class using a smartphone or laptop. They use digital platforms which facilitate them to learn (R. P. Rahayu \& Wirza, 2020).

Many educational institutions have practiced integrating technology in the learning process for years. The process is so-called blended learning. However, due to the outbreak of the Covid-19, all educational institutions are forced to shift traditional classrooms into online mode. Consequently, most teachers and students are ready to implement it, so many perceive it as harmful to the learning process.

Based on the communication type, online learning can be divided into two types: synchronous and asynchronous learning. Synchronous learning is the kind of online learning in which dynamic real-time communication between instructors and students or students and peers interactively. In contrast, asynchronous learning does not require any interactive communication since communication is only one way. So, the students are only provided with learning materials in a manageable time (Rahman, 2020).

\section{Online Learning Platforms}

Many digital platforms have been offered to teachers and students; yet, not all of them are widely used in Indonesia. Among all applications, the most popular platforms are WhatsApp, Video Conference, Google Classroom, YouTube, and university LMS.

\section{WhatsApp}

WhatsApp is one of the messaging applications that can send texts, images, files, videos, links, and voice. It can be used either on a mobile phone or laptop. As cited from WhatsApp official website, today, more than 2 billion people in over 180 countries use this 
application. WhatsApp is considered the easiest, most popular, and effective tool occupied by teachers among various online media. It is a proprietary, cross-platform instant messaging subscription service for smartphones and selected feature phones that use the internet for communication (Kheryadi, 2018).

Many studies about the effectiveness of using WhatsApp in online learning have been published (e.g., Ayuningtyas, 2018; Hamad, 2017; Jasrial, 2017; Kheryadi, 2018; Napratilora et al., 2020). All of them conclude that this messaging application can facilitate online learning, in this regard language learning, and can enhance students" performance and receive positive responses from the students.

\section{Video Conference}

Video conferencing is a technology that allows users in different locations to hold faceto-face meetings without having to move to a single location together (Kagan, 2019). The popular video conferencing applications in Indonesia are Zoom and Google Meet. During this pandemic, video conferencing is widely used in online learning. This platform allows the users to meet "face-to-face" in a virtual classroom though they are in separate places, even in a different country. Guzacheva (2020) uncovers that a video conference, in this regard Zoom, is an influential application to teach English in online learning. A Video conference has many features which are helpful in the learning and teaching process. The students can interact easily with their peers and teachers since they can see the face. Besides, the screen sharing feature also helps the students to understand the materials delivered by the teacher. Furthermore, the students can use the chatbox or raise hand feature to share their opinions or ask their inquiries. However, previous studies show that most of the students in Indonesia do not prefer this kind of platform due to some drawbacks, such as it consumes a lot of internet quota, cannot work in a remote area in which the internet connection is not harmful, and cannot store the teaching materials (e.g., Kheryadi, 2018; Mannong, 2020; Rahman, 2020).

\section{Google Classroom}

Google Classroom is a Learning Management System (LMS) provided by Google and can be accessed freely. The application makes it both the lecturers and the students easy to take part in a classroom. It also enables the members to be involved in a virtual classroom activity, where each member can interact with one another. Google Classroom involves a teacher, students, and a set of classroom activities such as submitting assignments, commenting, editing, checking on classmates' work, receiving feedback from teachers, and of course, receiving assignments (Subandoro \& Sulindra, 2019). Furthermore, Google classroom simplifies student-teacher communication, and it leads the teacher to have a complete vision concerning each student's progress. They can return their work along with the necessary comments so that the student can 
revise their assignments (Sukmawati \& Nensia, 2019). Google Classroom promotes an asynchronous communication platform since the students and the teachers do not see or interact directly through the application. However, the teacher can still control the students' learning progress in question and answer. Due to the limited interaction between students and teachers, it can reduce the students' anxiety (Salam, 2020).

\section{YouTube}

YouTube is an online platform that aims to upload, view, and share videos that are very popular worldwide. People use YouTube to entertain and learn any subject since many educational videos are available on the platform, including language learning. Many language teachers have started to use the website to teach different languages by uploading language learning videos and language learners worldwide like these videos, and some of these videos have reached millions of views (Alhamami, 2013). The use of YouTube in language learning also increases students' performance, particularly speak like a native, as well as increase their motivation (Alkathiri, 2019). Furthermore, this platform is also appropriate to be used by learners with learning styles (Nasution, 2019).

\section{University LMS}

Nowadays, many universities have started to develop and used their own Learning Management Systems (LMS). Like Google Classroom, university LMS offers features to facilitate the learning process, such as course management, assessment, tracking progress, grade book, communication tools, social connectivity, security \& privacy, and ubiquitous access (Turnbull et al., 2019). University LMS also integrates with the university system in which the monitoring of the learning process, including students' profiles, takes place (Iqbal, 2011).

\section{METHODS}

This article aims to uncover the students' preference of digital platforms in learning ESP during the Covid-19 pandemic, the factors affecting their preference, and their perception of those learning platforms. To achieve the purpose of the study, a descriptive qualitative design is applied. Qualitative research is a research method that collects and analyses data in the form of humans' words and deeds without attempting to quantify the qualitative data obtained (Bugis, 2019).

The participants of this study were 112 freshmen of a state university in Makassar who learn English for Specific Purposes (ESP), comprising 95 females and 17 males with ages ranged between 16-23 years old. The participants consisted of 3 majors; there are 32 students (28,57\%) from Chemistry Department, 41 students (36,61\%) from Mathematics Education Department, and 39 students $(34,82 \%)$ from the Islamic Education 
Management department. All the participants were involved in remote learning for one semester (16 meetings) through WhatsApp, Google Classroom, University LMS, YouTube, and Video Conference (Zoom and Google Meet).

In order to collect the data, a questionnaire that consists of close-ended and open-ended questions was distributed to the participants. Since, at the moment, the outbreak of the Covid-19 still becomes the primary issue, the questionnaire was spread through Google Form to the participants. A close-ended part was used to reveal the students' preferences and investigate factors affecting their preferences. In addition to that, to uncover their perception and reason to prefer a specific learning platform, an open-ended part was used.

\section{FINDINGS}

\section{Student's Preference of Learning Platform}

The data of students' preferences were presented in the form of a percentage. Figure 1 shows that the majority of students prefer WhatsApp (78\%). Next, $12 \%$ of students choose Video Conference, such as Zoom and Google Meet. Furthermore, $4 \%$ of participants prefer Google Classroom as the best platform used in learning English, and none of them either choose University LMS or have another option of the unmentioned platform.

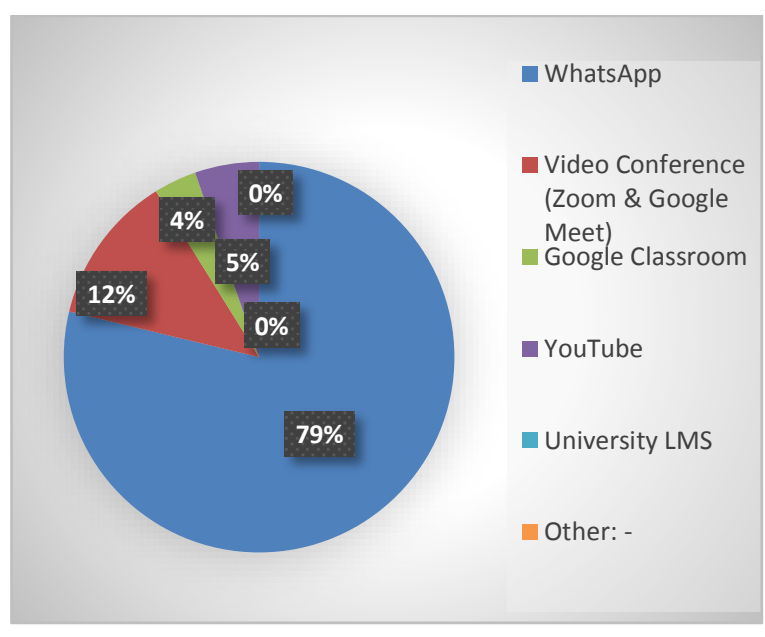

Figure 1. Students' Preference of Learning Platform

\section{Factors Affecting Student's Preferred Learning Platform}

In order to reveal the factors that influence the students in deciding the platform, their background information needs to be explored. The students' background information is classified based on students' demographics, in this regard, residence location, and economic constraints, particularly parental income.

Table 1. Students' Residence Location

\begin{tabular}{lcccc}
\hline & Urban & $\begin{array}{c}\text { Sub- } \\
\text { Urban }\end{array}$ & Rural & Total \\
\hline Frequency & 13 & 24 & 75 & 112 \\
\hline Percentage & $11,61 \%$ & $21,43 \%$ & $66,96 \%$ & $100 \%$ \\
\hline
\end{tabular}

Table 2. Parents' Income

\begin{tabular}{lcccc}
\hline & $\begin{array}{c}<5 \\
\text { million/ } \\
\text { month }\end{array}$ & $\begin{array}{c}\mathbf{5 - 8} \\
\text { million/ } \\
\text { month }\end{array}$ & $\begin{array}{c}>\mathbf{8} \\
\text { million/ } \\
\text { month }\end{array}$ & Total \\
\hline Frequency & 102 & 9 & 1 & 112 \\
\hline Percentage & $91,07 \%$ & $8,03 \%$ & $0,89 \%$ & $100 \%$ \\
\hline
\end{tabular}

\section{Students' Perception of Learning Platform}

The qualitative data were gathered from the open-ended questionnaires in which the 
students elaborate their perception and their reasons to choose a specific application. WhatsApp becomes the first application explored in this study since it gained the first rank of application that the students prefer with $79 \%$. In order to make it easy to understand, abbreviations such as $R, 1$, and WA are used. $R$ refers to response; 1 refers to the number of data display in this section, and WA refers to the WhatsApp application that is explained. The findings are as follows:

R1'This application is easy to operate' (WA-1)

R2'Using this application allows me to interact with my lecturer and other classmates' (WA-2)

R3'It can be accessed even in the remote area in which the internet connection is very bad' (WA-3)

R4'During the lecturing process, I can still access other application which I need, such as online dictionary' (WA-4)

R5'It doesn't cost a lot of internet quota so I don't burden my parents to buy quota' (WA-5)

R6'In learning grammar and pronunciation, Voice Note that sent by lecturer explaining the rule is very useful and can be played when I learn independently' (WA-6)

R7'For the materials that need a detailed explanation, the lecturer can use the Voice Note feature. It helps us understand the materials.' (WA-7)

R8'If the internet connection is lost in my village, I still can access and follow the materials when the connection is back even the class is already over' (WA-8)
R9'The learning materials (text, file, link, photo, audio and video) are saved properly so it is easy to access when it is necessary' (WA-9)

R10'Using WA is good as long as the lecturer explains the materials clearly.' (WA-10)

Despite many positive perceptions of using WhatsApp, some students also mention the shortcoming of this application which are provided in the excerpts below:

R11'All students' activity is hard to control whether they really standby on this WA group until the class is over or just post their chat at the beginning of the meeting and then "leave" the class' (WA-11)

R12'Using WA consumes more time since the lecturer needs time to type what she wants to say so we cannot discuss a lot of the materials' (WA-12)

R13'The explanation which is given through Voice Note WA is not as complete as Video Conference' (WA-13)

R14'Since a lot of texts coming in the group, it is quite difficult to scroll the text from lecturer' (WA-14)

The second rank of applications preferred by the students is a video conference. They revealed that using video conferences, including Zoom and Google Meet, help them understand clearly the explanation from the lecturer. It also allows them to interact directly with lecturers and classmates. During the students' presentation, this application is easy to operate, and they can discuss the material quickly. Finally, the students feel more focused when learn using Video conferences. The detailed excerpts are 
presented below (abbreviation VC stands for Video Conference):

R15'I can interact directly with my lecturer and classmate when using Video Conference instead of other application' (VC-1)

R16'The explanation from the lecturer is more detailed and understandable when using Video Conference, especially when she utilizes screen share feature' (VC-2)

R17'Using video conference is very useful when I am asked to present the material and did class discussion' (VC-3)

R18'This application is easy to operate' (VC-4)

R19'I am more focus on studying when the lecturer use Video Conference' (VC-5)

As presented in Figure 1, Video Conference is only preferred by $12 \%$ of respondents. The majority of students consider the drawback of this application. Most respondents think it is a high-consuming internet quota, so students with low income feel intimidated. Besides, students who reside in a remote area where the internet connection is in a terrible state that it is hard for them to join the meeting. Even if they succeed in joining it, they merely see the face or the screen of the lecturer and cannot listen to the lecturer's voice, so they cannot follow the materials at all. Additionally, this application cannot save the materials, so those who cannot join the meeting will miss all the materials. Finally, the students feel stressed when they cannot join the meeting due to a bad internet connection since they are afraid of being negatively evaluated due to missing the class.
R20'Video conference consumes a lot of internet quota' (VC-6)

R21'It cannot save the material so I don't write the lecturer's explanation, I will miss all the materials' (VC-7)

$\mathrm{R} 22^{\prime}$ In my village, the internet connection is very bad and sometimes lost. I usually cannot join the meeting or even I can join, I cannot hear what the lecturer says. I only can see her face' (VC-8)

R23'I feel insecure when the lecturer uses Video Conference since sometimes I cannot join the meeting due to a bad internet connection. I am afraid if she considers me absent' (VC-9)

The third top application rated by the students is YouTube (5\%). There were 6 out of 112 students who voted for this platform. The respondents argued that the explanation of the speaker on YouTube is very detailed and exciting. Other students also stated that this application is not interactive, so if they have any questions, they feel complicated to comment since the answer will be in written form.

R24'I enjoy learning English using YouTube. The explanation is very clear and interesting' (YT-1)

R25'Learning using YouTube is very limited. I cannot directly ask the question if I need further explanation. I have to write my answer in the comment box and waiting for the reply in the written form' (YT-2)

The fourth preferred application is Google Classroom which gained $4 \%$ of total respondents. They perceived that Google Classroom is easy to use and very useful in arranging their learning material. Furthermore, 
the instruction given by the lecturer is more explicit, and they can directly ask questions in the comment column.

R26"Easy to share learning materials, especially if the lecturer shares a video explaining about the lesson so the students can easily ask the question if any." (GC-1)

R27"Google classroom is useful in arranging learning materials, including grading assignments and easy to understand the instruction given by the lecturer." (GC-2)

All of the respondents negatively perceived the use of the university Learning Management System (LMS). They argue that the application is difficult to operate since many features appear in the display while not all the features were used by both lecturers and students in the learning process. Additionally, this application cannot be accessed in a remote area if the internet connection is terrible. Whereas this application is complete. It has a video conference and attendance list feature beside the facility to arrange the learning materials.

R28'University LMS is actually quite complete of facilitating our learning process; however, sometimes I cannot access it if the internet connection is bad in my village' (LMS-1)

R29'I feel confused when I operate university LMS. It is difficult to use since there are a lot of unused buttons' (LMS-2)

The students were also asked about the criteria of online learning that they desire. They wanted the interaction between a lecturer and students and students and students to be done actively. Moreover, they hope the materials can be explained clearly by the lecturer without being afraid that they will run out of internet quota.

Finally, the students argue that it is difficult for them to choose only one best application. They state that there is no one perfect application to be utilized during this emergency remote learning. It must be combined with other applications to make the learning process run properly. So, at least they need two kinds of applications; one application for interacting with lecturers and classmates, including explaining the material, WhatsApp or video conference, and one application for managing learning materials and assignments, that is Google Classroom. University LMS combines the two kinds of applications; however, it is pretty tricky to use since there are many features, while the other applications mentioned above are easy to operate.

The students hope that the learning process can be returned into face-to-face mode. They argue that the use of various platforms cannot replace offline learning. Many things are missing from this emergency remote learning which is supposed to be experienced by the students. Even so, they genuinely understand that face-to-face mode cannot be implemented at this moment; thus, to keep the learning process still running, remote learning becomes the only solution. 
R30'Sometimes there are materials which must be explained directly and hard to understand via online.' (OL-1)

R31'Interaction between lecturer and students is very limited.' (OL-2)

R32'Lack of facilities makes me uncomfortable to study during this outbreak.' (OL-3)

\section{DISCUSSION}

Although the outbreak of the Covid-19 pandemic has led our educational system to shift from face-to-face into online mode, the learning process still can run regularly due to the advancement of technology. The advancement of technology also results in various digital platforms that can be used as the device to facilitate the learning process. The platforms used for daily communication devices are now used as the main application in learning, particularly in language learning.

As many results, the students' eyesight in the utilization of the platform in learning ESP during the covid-19 pandemic is they perceived positively towards the use of WhatsApp as the device to facilitate language learning as it has several advantages; they are the application is easy to operate, it does not consume a lot of internet quota, it works well in the remote area in which the internet connection is terrible, it can save learning materials (text, file, link, photo, audio, and video) and it can be used to interact easily with lecturer and friends. This finding is similar to Mannong's (2020) study since the application is familiar for them, easy to access, and can work well even under poor signals. Similarly, this result supports a study by
Jasrial (2017) that the students can read and write the materials given by their teachers more than once whenever they want. They are free to ask their classmates and their teachers through WhatsApp when she/he gets difficulties, or there is something not clear enough about the learning material given. Furthermore, this result is also in line with the previous findings by Kheryadi (2018) that the students have a positive attitude to the use of WhatsApp in learning the foreign language since allows them to engage actively in online conversation and it finally leads them to be enthusiastic in learning English.

Students highly prefer the application which does not drain the internet quota since most of them came from families whose income is classified as low. Therefore, the students feel intimidated if they have to spend much funding on purchasing an internet quota. Besides, most students reside in a rural area where the connection is unstable and sometimes lost. Mannong (2020) conducted her research in Makassar and found some barriers students face in remote learning, such as limited quota and unstable signal strength. Thus, lack of facilities becomes the central issue during this outbreak. Internet facilities in South Sulawesi are not evenly developed, particularly in remote areas, so the students who reside there face many problems with the connection. These findings are also in line with Rahman (2020), who found that students' demographic background and economic constrain affect their preference in learning digital platforms. 
Furthermore, the current study reveals that many students also prefer using video conferences, particularly Zoom and Google Meet. The students perceive positively the interaction between lecturers and students and students and peers, and this kind of application is experienced can facilitate them for it. Online learning with high intensity of interaction makes the students more motivated in the study. Thus, this learning communication promotes a synchronous type in which the interaction between those involved in learning is required (Guzacheva, 2020). However, most of the students do not prefer this kind of platform since it consumes a lot of internet quota, cannot work in a remote area where the internet connection is not harmful, and cannot store the teaching materials.

The third top application rated by the students is YouTube. The respondents argued that the speaker's explanation in YouTube is very detailed and exciting, as Alhamami (2013) stated that some of the criteria of YouTube videos are clear and attractive. The video is sometimes completed with audio and engaging illustrations so the students can feel more motivated, reduce the negative effect of anxiety, and enjoy studying. Other students also stated that this application is not practical since if they have any questions, they feel complicated to comment since the answer will be in written form.

The fourth preferred application is Google Classroom. They perceived that Google Classroom is easy to use and very useful in arranging their learning materials. These findings are in line with a study by Subandoro \& Sulindra (2019), which uncovers that Google classroom can help students facilitate online learning, especially managing their learning materials. Furthermore, the instruction given by the lecturer is more precise, and they can directly ask questions in the comment column. Besides, the students can reread the materials after class hours. These findings support Salam (2020) that Google Classroom brought their courses to their face to participate and continue work on their classes beyond the working hours.

Even though the features are pretty complete, all respondents negatively perceived the university Learning Management System (LMS) since the application is challenging to operate. They argue that many features appear in the display. In contrast, not all the features were used by lecturers and students in the learning process and sometimes cannot be accessed remotely if the internet connection is terrible. Thus, it can be suggested to the university to improve the performance of the LMS to make the study process using this platform more effective.

Although the students perceived online learning beneficial during the outbreak of the Covid-19, they argue that face-to-face mode is still irreplaceable, as under that of Febrianto et al. (2020). Many things are missing from this emergency remote learning which is supposed to be experienced by the students, such as focusing on lecturers' explanation, interact 
directly with lecturers and peers, students' presentation without being worried about internet quota, discussing with other friends, etc. Even so, they genuinely understand that face-to-face mode cannot be implemented at this moment. Thus, to keep the learning process still running, remote learning becomes the only solution. This finding supports the study by Kulal \& Nayak (2020) that the students are comfortable with online classes during the Covid-19 outbreak. However, they do not believe that online learning can replace traditional classrooms.

Finally, the findings of this study also imply that there is no one perfect digital platform that can replace traditional classrooms since all the applications used have shortcomings in the students' eyesight and many things missing during this online learning. So, to keep it running effectively, the combination of several platforms is required to be utilized as by that of Amin \& Sundari (2020).

\section{CONCLUSION}

Based on the explanation above, it is found that the students' preference of digital platform in learning ESP during the Covid-19 pandemic is WhatsApp. The factors affecting students' preference of the platform are demographics, residence, and economic constraints, particularly their parents' income. The students highly prefer the one that does not drain the internet quota and can still work correctly in which the internet connection is not strong since most of the students come from families whose low income and reside in rural areas. Besides, the students also prefer synchronous learning in which the learning process runs interactively between lecturers and students and students and peers. There is no perfect digital platform that can replace traditional classrooms since many things are missing during this online learning. So, to keep it running effectively, the combination of several platforms is required to be utilized.

\section{REFERENCES}

Abidah, A., Hidaayatullaah, H. N., Simamora, R. M., Fehabutar, D., \& Mutakinati, L. (2020). The Impact of Covid-19 to Indonesian Education and Its Relation to the Philosophy of "Merdeka Belajar." Studies in Philosophy of Science and Education. https://doi.org/10.46627/sipose.v1i1.9

Alhamami, M. (2013). Observation of Youtube Language Learning Videos (YouTube LLVs). Teaching English with Technology, 3, 3-17.

Alkathiri, L. A. (2019). Students' Perspectives towards Using Youtube in Improving EFL Learners' Motivation to Speak. Journal of Education and Culture Studies. https://doi.org/10.22158/jecs.v3n1p12

Amin, F. M., \& Sundari, H. (2020). Efl students' preferences on digital platforms during emergency remote teaching: Video conference, Ims, or messenger application? Studies in English Language 
and

Education.

https://doi.org/10.24815/siele.v7i2.16929

Amoah, C. A., \& Naah, A. M. (2020). Pre-Service Teachers' Perception of Online Teaching and Learning During the COVID - 19 Era. International Journal of Scientific Research and

Management.

https://doi.org/10.18535/ijsrm/v8i10.el01

Astri, Z. (2018). The Use of Total Physical Response Method for Different Learning Styles in English Vocabulary Development. Seltics Journal: Scope of English Language Teaching, Literature and Linguistics, 1(1), 25-38.

Ayuningtyas, P. (2018). Whatsapp: Learning on the go. Metathesis: Journal of English Language, Literature, and Teaching. https://doi.org/10.31002/metathesis.v2i2. 629

Bugis, E. H. (2019). Pendekatan Kualitatif. In I. S. Wekke (Ed.), Metode Penelitian Pendidikan Bahasa (1st ed., pp. 48-71). Gawe Buku.

Febrianto, P. T., Mas'udah, S., \& Megasari, L. A. (2020). Implementation of online learning during the covid-19 pandemic on Madura Island, Indonesia. International Journal of Learning, Teaching and Educational Research.

https://doi.org/10.26803/ijlter.19.8.13

Ferreira, A., \& Santoso, A. (2008). Do students' perceptions matter? A study of the effect of students' perceptions on academic performance. Accounting and Finance. https://doi.org/10.1111/j.1467-

629X.2007.00239.x

Garrote, M. (2015). Teaching Effectively: ESP for Pre-service Primary Teachers. Revista de Didácticas Específicas, 13, 116-130.

Guzacheva, N. (2020). Zoom Technology as an Effective Tool for Distance Learning in Teaching English to Medical Students. Bulletin of Science and Practice. https://doi.org/10.33619/2414$2948 / 54 / 61$

Hamad, M. M. (2017). Using WhatsApp to Enhance Students' Learning of English Language "Experience to Share." Higher Education Studies. https://doi.org/10.5539/hes.v7n4p74

ILO. (2021). ILO: Uncertain and uneven recovery expected following unprecedented labour market crisis. http://www.ilo.org/global/about-theilo/newsroom/news/WCMS_766949/lang-en/index.htm

Iqbal, S. (2011). Learning Management Systems (LMS): Inside Matters. Information Management and Business Review. https://doi.org/10.22610/imbr.v3i4.935

Jasrial, D. (2017). Utilizing Whatsapp Application For Teaching English Language: Why And How ? Isbn: 978-602-70378-2-3. 
Kagan, J. (2019). Video Conferencing. https://www.investopedia.com/terms/v/v ideo-conferencing.asp

Kheryadi, K. (2018). The Implementation of "WHATSAPP" as a Media of English Language Teaching. Loquen: English Studies Journal. https://doi.org/10.32678/loquen.v10i2.68 5

Kulal, A., \& Nayak, A. (2020). A study on perception of teachers and students toward online classes in Dakshina Kannada and Udupi District. Asian Association of Open Universities Journal. https://doi.org/10.1108/aaouj-07-20200047

L. Smart, K., \& J. Cappel, J. (2006). Students' Perceptions of Online Learning: A Comparative Study. Journal of Information Technology Education: Research. https://doi.org/10.28945/243

Mannong, A. B. M. (2020). The Students' Eyesight: The Effectiveness of LearningBased Applications on ELT in Pandemic Era. ETERNAL (English Teaching, Learning \& Research Journal), 6(2), 394-407. https://doi.org/https://doi.org/10.24252/ Eternal.V62.2020.A14

Mulyadi, D. (2018). Efl student teachers' perception and challenges toward online platforms in language pedagogy. 2nd
English Language and Literature International Conference (ELLiC).

Mulyani, Fidyati, Suryani, Suri, M., \& Halimatussakdiah. (2021). University students' perceptions through e-learning implementation during covid-19 pandemic: Positive or negative features dominate? Studies in English Language and Education.

https://doi.org/10.24815/siele.v8i1.17628

Napratilora, M., Lisa, H., \& Bangsawan, I. (2020). Using WhatsApp as a Learning Media in Teaching Reading. MITRA PGMI: Jurnal Kependidikan

MI.

https://doi.org/10.46963/mpgmi.v6i2.129

Nasution, A. K. R. (2019). YouTube as a Media in English Language Teaching (ELT) Context: Teaching Procedure Text. Utamax : Journal of Ultimate Research and Trends in Education.

https://doi.org/10.31849/utamax.v1i1.278 8

Putra, B. A. (2020). English Teachers' Perceptions on English Teaching Difficulties Using Online Platform during Covid-19 Pandemic at SDIT Ar Risalah Surakarta in 2020/2021 Academic Year. Universitas Muhammadiyah Surakarta.

Rahayu, M. K. P. (2019). Barriers to Use ELearning Platform in Indonesia Higher Education: Factors Related to People and 
Organization.

https://doi.org/10.2991/icoi-19.2019.83

Rahayu, R. P., \& Wirza, Y. (2020). Teachers' Perception of Online Learning during Pandemic Covid-19. Jurnal Penelitian Pendidikan, 20(3), 392-406.

Rahman, K. (2020). LEARNING AMID CRISIS: EFL STUDENTS' PERCEPTION ON ONLINE LEARNING DURING COVID-19 OUTBREAK. ETERNAL (English, Teaching, Learning, and Research Journal). https://doi.org/10.24252/eternal.v62.202 0.a1

Rasmitadila, Aliyyah, R. R., Rachmadtullah, R., Samsudin, A., Syaodih, E., Nurtanto, M., \& Tambunan, A. R. S. (2020). The perceptions of primary school teachers of online learning during the covid-19 pandemic period: A case study in Indonesia. Journal of Ethnic and Cultural Studies. https://doi.org/10.29333/ejecs/388

Salam, U. (2020). The Students' Use of Google Classroom in Learning English. JPI (Jurnal Pendidikan Indonesia).

Subandoro, P. S., \& Sulindra, E. (2019). Optimizing Collaborative Learning: Using Google Classroom in Business English Correspondence Class. VOCATIO: Jurnal IImiah IImu Administrasi Dan Sekretari.
Sukmawati, S., \& Nensia, N. (2019). The Role of Google Classroom in ELT. International Journal for Educational and Vocational Studies.

https://doi.org/10.29103/ijevs.v1i2.1526

Turnbull, D., Chugh, R., \& Luck, J. (2019). Learning Management Systems: An Overview. In Encyclopedia of Education and Information Technologies. https://doi.org/10.1007/978-3-319-

60013-0_248-1

UNESCO. (2021). \#LearningNeverStops: Covid-19 Education Response. https://en.unesco.org/covid19/educationr esponse/globalcoalition

Windiarti, S., Fadilah, N., Dhermawati, E., \& Pratolo, B. W. (2019). Teachers' Perception toward the Obstacles of E-Learning Classes. Ethical Lingua: Journal of Language Teaching and Literature. https://doi.org/10.30605/25409190.v6.11 $7-128$

Zaharah, Z., Kirilova, G. I., \& Windarti, A. (2020). Impact of Corona Virus Outbreak Towards Teaching and Learning Activities in Indonesia. SALAM: Jurnal Sosial Dan Budaya Syar-I. https://doi.org/10.15408/sjsbs.v7i3.15104 